\section{An Insect Funeral}

Mrs. E. F. Hillier, Gregherd, Sask.

I wonder how many have seen a funeral take place in the insect world. I had occasion to witness such an event one fine spring day.

As I walked in my garden I noticed a rather large black beetle which seemed to be burdened down with some kind of load. On looking closer I found it to be a cutworm. It reached a furrow at the edge of the garden. This it could not climb with its "corpse" so I thought I would assist it. I picked up the worm and placed it on the top edge of the furrow and urged the beetle up under its own power. It found the corpse again and continued on its way. It crawled about four more feet out on the open ground and left the corpse lying while it proceeded to dig a grave. It started to throw the dirt out with its hind feet and then it turned around and backed down the hole and threw out some more dirt with its front feet. I forgot to say that the beetle had another corpse laid out in the same place.

After the grave was completed he prepared to drag the corpse into it. He went through quite a performance as if "laying out" the body properly. Then he took it to the hole. The other cutworm disappeared likewise into another hole. While watching this performance I saw another of these beetles in flight.

could find shelter. Those that could not reach the valley with its trees perished.

In closing I would like to add a note of warning to readers who feed birds in an emergency. If feeding bird seed, spread it in only one place, namely a bare spot close to the house. Since I had a large quantity of bird seed I fed several dozen birds and this past few weeks have been very busy pulling $\mathrm{up}$ noxious weeds sprung from left-over seed. Bird seed is just a mixture of weeds with some grass seed. Mustard is one very prevalent seed and there are some I can't even identify. Reed Canary Grass seed is preferred by birds to rape, mustard, etc.

\section{Inheritance}

These gifts my father left to me:

To know the language of a tree;

To hail as friends, the birds and flowers;

To see the sun behind the showers;

To sense God in the sun and rain; To feel the good of grief and pain; To dread no storms on sea or land, But see in them a ruling hand;

To love the jewels in the sky;

Find beauty in the clouds on high;

Wind melodies to understand;

Where needed, lend a helping hand;

To hold a friend of greater worth, Than other treasures of the earth;

To be content with simple things. If only these, Dame Fortune brings;

To place the heart above the mind; In every creature good to find;

To laugh at blows Fate deal to me; To keep my courage strong in me;

To make good use of time spent here; To think of death without a fear;

To live; let live, and trust in God, Until I'm laid beneath the sod.

Louise Mathern

\section{Yellow Prairie Lilies}

Charles Thacker, Broadview, Sask.

On July $15 \mathrm{Mr}$. Alex Anderson, of Broadview, while out for a drive with his family came upon two plants that are very unusual. Both were lily plants, size and pattern of sepals and petals the same as the regular Western Red Lily but these blooms were a lovely yellow, completely so, save for the faintest yellow green spotting at the base of the flower.

I saw these flowers, the first I have ever seen. I presume they will be the same as those referred to by C. Stuart Francis, of Torch River, in the "Blue Jay" for Oct., Nov., Dec., 1951. 